\title{
Aquatic Species Project Report: FY 1991
}

Contributing Authors (NREL):

E. E. Jarvis, T. G. Dunahay, K. G. Zeiler,

P. G. Roessler

L. M. Brown, National Renewable Energy Laboratory (NREL)

S. Sprague, U. S. Department of Energy (DOE)

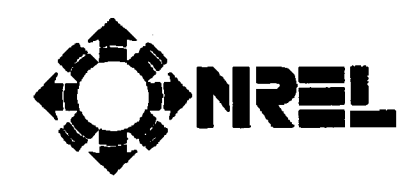

National Renewable Energy Laboratory 1617 Cole Boulevard Golden, Colorado 80401-3393

A Division of Midwest Research Institute Operated for the U.S. Department of Energy under Contract No. DE-AC02-83CH10093

Prepared under task no. BF111010

April 1992 


\section{On September 16, 1991 the Solar Energy Institute was designated a national laboratory, and its name was changed to the National Renewable Energy Laboratory.}

\section{NOTICE}

This report was prepared as an account of work sponsored by an agency of the United States government. Neither the United States government nor any agency thereof, nor any of their employees, makes any warranty, express or implied, or assumes any legal liability or responsibility for the accuracy, completeness, or usefulness of any information, apparatus, product, or process disclosed, or represents that its use would not infringe privately owned rights. Reference herein to any specific commercial product, process, or service by trade name, trademark, manufacturer, or otherwise does not necessarily constitute or imply its endorsement, recommendation, or favoring by the United States government or any agency thereof. The views and opinions of authors expressed herein do not necessarily state or reflect those of the United States government or any agency thereof.

\section{Printed in the United States of America \\ Available from: \\ National Technical Information Service \\ U.S. Department of Commerce \\ 5285 Port Royal Road \\ Springfield, VA 22161 \\ Price: Microfiche A01 \\ Printed Copy $\mathrm{AO} 3$}

Codes are used for pricing all publications. The code is determined by the number of pages in the publication. Information pertaining to the pricing codes can be found in the current issue of the following publications which are generally available in most libraries: Energy Research Abstracts (ERA); Government Reports Announcements and Index (GRA and I); Scientific and Technical Abstract Reports (STAR); and publication NTIS-PR-360 available from NTIS at the above address. 


\section{PREFACE}

This report summarizes the progress and research accomplishments of the Aquatic Species Project, field managed by the National Renewable Energy Laboratory (NREL), through October 1991. This report includes an overview of the entire project and a summary of individual research projects. The project receives its funding through the Biofuels Systems Division of the Department of Energy.

For further details, contact the NREL Aquatic Species Project Manager, Dr. Lewis Brown, at (303) 231-1321. 


\section{TABLE OF CONTENTS}

$\begin{array}{ll}\text { I. Project Overview } & 1\end{array}$

$\begin{array}{ll}\text { II. Culture Collection } & 9\end{array}$

III. Genetic Analysis of Organisms 10

$\begin{array}{ll}\text { IV. Microalgal Transformation } & 15\end{array}$

V. Lipid Gene Cloning $\quad 20$

VI. Environment, Safety, and Health and Quality Assurance 24

$\begin{array}{ll}\text { VII. References } & 26\end{array}$ 


\section{PROJECT OVERVIEW}

\section{INTRODUCTION}

When stimulated by environmental stress, many species of aquatic microalgae produce lipids that can be processed into diesel oil or gasoline. These algae have growth rates as high as five times those of most terrestrial plants, and some species flourish in saline or brackish water unsuitable for human or traditional agricultural use. In addition, microalgae require large quantities of carbon dioxide for growth and lipid production, thereby reducing the concentration of atmospheric carbon dioxide.

Studies have shown that economic fuel production will require the microalgae to be grown in intensive culture in large outdoor ponds. The system design consists of 6-in.-deep, racewayshaped ponds with a paddlewheel for circulating the water. Carbon dioxide and other nutrients are injected into the culture to optimize algal growth and lipid production.

Researchers in the project have collected and studied more than 3000 strains of microalgae from desert and saline environments. From these, a number of promising lipidproducing species have been identified. These organisms grow over a wide range of salinities, produce significant quantities of lipid oils, and achieve growth rates of nearly three doublings per day. Some of these species tolerate temperatures of $100^{\circ} \mathrm{F}$ or higher.

Research is now focused on applying genetic techniques to enhance the lipid production of microalgae. This effort builds on extensive strain characterization research, as well as biochemical studies of the metabolic pathways for lipid synthesis. Using non-genetic methods, scientists have already improved the lipid content of the cell from the $5 \%$ to $20 \%$ found in nature to more than $60 \%$ in the laboratory and more than $40 \%$ in outdoor culture. 
Microalgae production facilities are well-suited to areas with high solar radiation, inexpensive, flat land, adequate saline water, and an inexpensive source of carbon dioxide. The desert Southwest meets all of these requirements. Large coal-burning power plants in the region offer an excellent potential source of carbon dioxide for microalgae farms.

Coupling a microalgae farm with a power plant or other source of carbon dioxide provides a way to produce liquid transportation fuels and improve the environment at the same time. The microalgae essentially recycle the carbon dioxide from the power plant's stack gases into a secondary energy product (diesel fuel or gasoline). Although this carbon dioxide is eventually released when the fuel is burned, the process effectively doubles the amount of energy generated for a given quantity of carbon dioxide. Studies have shown that land and saline water are available in New Mexico and Arizona, for example, to support extensive microalgae facilities. The carbon dioxide emissions from all the power plants in these two states could be trapped by microalgae farms covering about $0.25 \%$ of the total land area. If this technology is expanded to other states, or projected future capacity is brought on line in Arizona and New Mexico, the farms could supply at least 2 quadrillion Btu of energy (equivalent to $15 \%$ of the gasoline used in the United States) in the form of liquid fuels. 


\section{OVERVIEW OF RESEARCH}

Researchers in the Aquatics Species Project focus on the use of microalgae as a feedstock for producing renewable, high-energy liquid fuels such as diesel. It is important for the United States to develop alternative renewable oil sources because $42 \%$ of the current energy market in the United States is for liquid fuels, and $38 \%$ of these fuels are imported. The latter figure is expected to rise to more than $50 \%$ soon, increasing the U. S. trade deficit and our vulnerability to disruptions in petroleum supplies. In 1979, the U. S. Department of Energy (DOE) and the National Renewable Energy Laboratory (NREL) initiated the Aquatic Species Project as part of the overall effort in biofuels. The project began to focus exclusively on fuels from microalgae in 1982. Estimates show that the technology being developed by the project can provide as much as $7 \%$ of the total current U.S. energy demand.

The program's basic premise is that microalgae, which have been called the most productive biochemical factories in the world, can produce up to 30 times more oil per unit of growth area than land plants. It is estimated that 150 to 400 barrels of oil per acre per year could be produced with microalgal oil technology. Initial commercialization of this technology is envisioned for the desert Southwest because this area provides high solar radiation and offers flat land that has few competing uses (hence low land costs). Similarly, there are large saline aquifers with few competing uses in the region. These could provide a suitable, low-cost medium for the growth of many microalgae.

The project has begun to assume additional importance for its potential contribution to the environment. Potential global climate changes are projected as a result of the release of carbon dioxide from fossil fuel combustion. These global climate changes have the potential of producing economic and geopolitical changes with profound impacts on our economy and the energy industry. The production of diesel fuel by microalgae requires substantial quantities of carbon dioxide as a nutrient. In areas where microalgae fuel plants operate in tandem with fossil 
fuel plants to scrub carbon dioxide from flue gases, contributions to the release of carbon dioxide could be significantly reduced.

The project has supported research at NREL in Golden, Colo., as well as in industry, other government laboratories, and universities.

\section{Project Goal}

The goal of the Aquatic Species Project is to develop the technology base for large-scale production of oil-rich microalgae. The project is also developing methods to convert the microalgal lipids into liquid fuels needed for industry and transportation.

\section{Project Objectives}

Specific long-term objectives of the project are to:

- Genetically engineer microalgae for high lipid production at high growth rates.

- Identify "trigger" points in biochemical pathways of algae that turn lipid production on and off.

- Develop inexpensive, large-scale, outdoor mass culture technologies to grow microalgae.

- Evaluate resource requirements for large-scale production of oil from microalgae as well as the environmental impact of such activities in the desert Southwest of the United States.

- Develop technologies for converting microalgal lipids into high-value liquid transportation fuels, particularly diesel. 
- Transfer the technologies to the private sector for continued development and rapid commercialization by involving industry in the research process as early as possible.

\section{Description of the Aquatic Species Project Elements}

\section{Production}

The NREL culture collection contains microalgal strains that produce large amounts of lipids and grow rapidly, but not necessarily at the same time or in a controllable manner. Genetic improvement will be necessary to develop strains with the characteristics necessary to meet the overall project technical and economic goals, including predictable growth performance and controllable lipid yield. The genetic engineering process requires methods for getting genes (DNA) out of cells (cloning), modifying the gene, and reintroducing it into the microalgae. The modified genes would then confer one or more desired characteristics such as increased lipid content to the algae.

\section{Extraction and Conversion}

Methods need to be developed for economical extraction of lipids from microalgae and conversion of lipids to gasoline and diesel substitutes. Untreated lipids have too high an oxygen content and viscosity to be used in standard engines. The primary goal of the conversion element is to economically convert a high proportion of the algal lipids to diesel fuels and to improve the overall economics by converting the balance of the biomass to biogas or other high-energy products. 


\section{Engineering Design}

The technology to produce economic liquid fuels from microalgae will require the growth of microalgae on a large scale. Systems to maintain optimal levels of nutrients, carbon dioxide, salinity, and temperature must be developed and tested. The engineering design element's goal is to develop large-scale outdoor facilities that allow the production goals to be met and to reduce the economic costs of such a system to those targeted by the project's economic analysis. It is hoped that future work in this area will allow the evaluation of various mass-culture and harvesting systems and technologies in an effort to increase outdoor algal productivities and decrease the cost of operating such a facility.

\section{Analysis}

Economic and resource analyses provide input to project management so that research directions and priorities can be set. The analysis element's goal is to support the technology development by determining cost goals, economic sensitivities, resource assessments, and environmental impacts as new data are developed. To do this, researchers will conduct ongoing economic analyses. Resource and environmental assessments will be conducted to identify potential constraints, identify and address data gaps, and provide project guidance.

\section{Project Highlights}

\section{FY 1991 Accomplishments}

The primary area of research has been the effort to genetically improve microalgae in order to control the timing and magnitude of lipid accumulation. Increased lipid content will have a direct effect on fuel price, and the control of lipid content is a major project goal. The enzyme acetyl-CoA carboxylase (ACC) was isolated and characterized previously; ACC appears to have an important role in controlling the levels of lipids accumulated in microalgal cells. A 
major accomplishment in FY 1991 was the isolation (cloning) and partial characterization of the gene encoding ACC from the diatom Cyclotella cryptica.

Gene probes have been designed for cloning of two other algal genes: nitrate reductase (NR) and orotidine-5'-phosphate decarboxylase (OPD). NR is an enzyme important in the partitioning of photosynthetic carbon products among lipids and other cellular components; understanding the genetics and biochemistry of this enzyme may lead to another method of controlling lipid production. OPD is involved in pyrimidine biosynthesis. Both the NR and OPD genes will be useful as selectable markers for microalgal transformation. Algal cells mutant in one or the other of these two gene activities have been characterized.

Previous work focused on the application of a transient expression system to microalgae. The cell walls of a green algal species were removed by enzymatic treatment (protoplast formation) and a gene from the firefly (encoding luciferase) was introduced into these cells. This work was published (Jarvis and Brown 1991), and experiments have progressed on the further refinement of the system and attempts at application to other species.

A related project was the analysis of some of the key microalgal strains for their DNA composition. Several strains were rich in some modified bases while others did not have a substantial quantity of modified bases, and several of the green algae showed unusually high guanosine + cytosine (GC) content. Such information is useful for developing genetic transformation strategies and for choosing strains that are suitable for genetic manipulation. This work was completed during FY 1991 and submitted for publication.

\section{FY 1992 Plans}

Economic and engineering analyses will continue in the form of efforts to identify key technical achievements that may lead to reduction in fuel cost (fuel cost sensitivity analyses). This work will include use of the Algae Economic Model (AEM). The AEM is a FORTRAN 
computer model that aids in the identification of cost factors. The model includes biological, engineering, economic, and other parameters that can be specified.

Genetic engineering will continue to be a major area of effort in the project. This area has the potential to have a positive effect on product yield. The research in FY 1992 will focus on completing the analysis of the ACC gene from $C$. cryptica and on the cloning of two other genes, OPD and NR, for use as selectable markers in transformation studies. Efforts will concentrate on the production of gene libraries and probe development. Work will also continue on refining the methods for introducing genes into microalgal cells. 


\section{CULTURE COLLECTION}

The microalgal culture collection was transferred quarterly during FY 1991. Experiments using autoclavable media to replace filter-sterilized media were evaluated. At least 89 strains that were previously maintained in filter-sterilized media were transferred to autoclavable media. Such experiments have significantly decreased the amount of filter-sterilized media needed for the transfer and thus have reduced the overall effort required and potential for contamination. The current collection consists of 320 strains in the main collection, 34 strains in the cold water collection, and 80 strains in the clone collection for a total of 434 strains. 


\section{GENETIC ANALYSIS OF ORGANISMS}

\section{INTRODUCTION}

Any molecular genetic study should begin with a basic understanding of the genome of the organism of interest. An important aspect of the genome is the composition of the DNA at the nucleoside base level, which encompasses the presence of unusual bases, methylation, and the base ratios. These general aspects of the genome can reflect important biological characteristics. For example, DNA methylation can affect gene regulation, and thus a cell's response to environmental changes, and can be involved in defense (restriction/modification) systems. With respect to the genetic engineering project, DNA composition data are important when designing strategies for gene cloning and transformation.

The most commonly observed variation in the standard four base motif is the presence of methylated nucleosides, in particular 5-methyldeoxycytidine $\left(\mathrm{m}^{5} \mathrm{dC}\right)$ and 6-methyldeoxyadenosine $\left(\mathrm{m}^{6} \mathrm{dA}\right)$. These modifications have been implicated in defense (restriction/modification) systems (Modrich 1982) and in the regulation of gene expression in eukaryotes (Selker 1990). In higher plants, which have highly methylated genomes, hypomethylated regions appear to be associated with actively transcribed regions (Antequera and Bird 1988), and methylation has been found to inhibit transient gene expression (Hershkovitz et al. 1990). Cytosine methylation has also been detected in the algae (Shapiro 1976); it is used as a signal in restriction/modification systems in virus-infected Chlorella sp. (Van Etten et al. 1985).

Another aspect of DNA composition is the ratios of the nucleosides present in an organism. Such data, generally represented by the proportion of deoxyguanosine and deoxycytidine in the DNA nucleosides (or GC content), have been compiled for many species (reviewed in Normore 1976, Shapiro 1976). It is important to note that, while the presence of methylation in DNA is something that can change on a short time scale and in response to environmental stimuli, the GC content essentially changes only on an evolutionary time scale. The biological significance of an organism's GC content is not clear; however, unusually high or low GC content is often correlated to a similar bias in the organism's codon usage. For 
example, Chlamydomonas reinhardtii was shown to have a high GC content of $62 \%-66 \%$ (Normore 1976), which parallels a strong bias toward $G$ and $C$ nucleotides in its codon usage (e.g., Silflow and Youngblom 1986, Goldschmidt-Clermont and Rahire 1986). This bias may explain why the development of efficient nuclear transformation systems in Chlamydomonas required the use of homologous selectable markers (Debuchy et al. 1989, Kindle et al. 1989, Mayfield and Kindle 1990). Chlorella sorokiniana, another green alga, has been shown to have high levels of $\mathrm{m}^{5} \mathrm{dC}$, which may have inhibited early attempts at gene cloning (Cock et al. 1990). We have analyzed ten species of microalgae representing five classes. These include several of the strains previously identified as having the most potential in biotechnology and mass culture.

\section{METHODS AND RESULTS}

Microalgal DNA content data were reported previously (Dunahay et al. 1990). DNA was isolated from ten strains, six of which were isolates in the NREL culture collection (see Barclay et al. 1986). Total DNA was extracted from all of the species by a modification of the yeast nucleic acid isolation method of Hoffman and Winston (1987). Cells were grown in the appropriate medium to early stationary phase, harvested by centrifugation, and broken open by vortex mixing in the presence of glass beads and phenol/chloroform. The DNA was further purified by phenol/chloroform extractions, ethanol precipitations, ethidium bromide-cesium chloride density gradient ultracentrifugation and/or precipitation with hexadecyltrimethylammonium bromide (CTAB) to remove contaminating carbohydrates. Analysis of the nucleoside base composition of the DNA samples was done by Charles Gehrke and Ken Kuo at the Cancer Research Center of the University of Missouri in Columbia. Samples were enzymatically digested to yield monomeric deoxyribonucleosides, which were then resolved using reversed-phase high performance liquid chromatography (HPLC). Peaks were identified by comparison to known standards for both retention time and ultraviolet (UV) spectrum (Gehrke and Kuo 1990).

Two methylated nucleosides were detected in this study: $\mathrm{m}^{5} \mathrm{dC}$ and $\mathrm{m}^{6} \mathrm{dA}$. Only trace amounts of $\mathrm{m}^{6} \mathrm{dA}$ were detected in two of the organisms, Stichococcus sp. and Tetraselmis 
suecica. In contrast, $\mathrm{m}^{5} \mathrm{dC}$ is a major component of the total DNA of several of the algae. Only small amounts ( $<1$ mole \%) were observed in the diatoms Navicula saprophila, Nitzschia pusilla, and Phaeodactylum tricornutum (strains 646 and 642), and in the green algae C. reinhardtii and Stichococcus sp. Moderate amounts were seen in Crypthecodinium cohnii, Chlorella ellipsoidea, $T$. suecica, and the diatom C. cryptica. By far the most striking figure is for Monoraphidium minutum with a value of 11 mole $\%$ of $\mathrm{m}^{5} \mathrm{dC}$. About one out of three deoxycytidine residues in this green alga is methylated.

Another parameter obtained was the GC content, which is calculated as the percentage of the total deoxynucleosides that are either $\mathrm{dG}, \mathrm{dC}$, or $\mathrm{m}^{5} \mathrm{dC}$. A typical $\mathrm{GC}$ content for a eukaryotic cell is in the range of $35 \%$ to $50 \%$. The diatoms all showed values in this range. In general, the green algae showed higher GC values. C. reinhardtii showed a very high GC content of almost $62 \%$, which is consistent with previously published data (Normore 1976). The most notable of all the algae tested was again $M$. minutum with a GC content of approximately $71 \%$. The only green alga without an elevated GC content was Stichococcus sp., which gave a value of $45 \%$ GC.

Restriction analysis was also carried out in support of the HPLC data. The ability of a restriction enzyme to cleave DNA at its recognition site is informative in terms of the modification state and base composition of the DNA. In particular, the two enzymes MspI and HpaII are frequently used because they are differentially sensitive to methylation at $\mathrm{C}$ residues (Mann and Smith 1977, Waalwijk and Flavell 1978). Both enzymes cleave at the sequence 5'CCGG. However, Hpall will not cleave if either $\mathrm{C}$ is methylated; MspI will not cleave if the first $C$ is methylated, but is unaffected by methylation at the second $C$. As an example, DNA from $N$. saprophila, which was shown to have relatively little $\mathrm{m}^{5} \mathrm{dC}$, was cleaved to a similar extent by either enzyme. In contrast, $M$. minutum DNA was digested much less completely by HpaII than by MspI. This result supports the HPLC data that showed a high degree of methylation in this organism. The size distribution of the fragments generated by digestion with various enzymes also supports the high GC content determined in the HPLC analysis. Finally, such digests can also provide information on the specificity of DNA methylation. At least in the case of $M$. minutum, C methylation is clearly not random; data suggest that the methylation is 
biased toward the sequence CG, and possibly CXG. Such a bias has been reported in higher plants (Gruenbaum et al. 1981).

\section{DISCUSSION}

The algae were shown to be quite diverse in their DNA compositions, showing the presence of both modified bases and unusual GC levels. The most remarkable finding was the high degree of cytosine methylation and the unusually high GC content of $M$. minutum. Restriction analysis supported these findings and suggested that the methylation is sequence specific. Under the growth conditions used, $\mathrm{m}^{5} \mathrm{dC}$ comprised $11.5 \%$ of the total nucleosides in this green alga. This represents an even greater degree of methylation than is seen in higher plants, where typical levels of $\mathrm{m}^{5} \mathrm{dC}$ in the genome are 3-7 mole \% (Shapiro 1976). The biological role of methylated bases in microalgae is unknown. However, methylation in other organisms has been shown to play diverse roles in such important processes as gene regulation, mismatch repair, transposition, replication, and chromosome segregation (Messer and NoyerWeidner, 1988).

The representatives of two classes of green algae, the Chlorophyceae and Prasinophyceae, exhibited significantly higher GC contents than those seen for the Bacillariophyceae, the Dinophyceae, or for eukaryotic cells in general. This bias toward GC has been well documented in $C$. reinhardtii, where the high $\mathrm{GC}$ content is also reflected in a preference for $\mathrm{G}$ and $\mathrm{C}$ in its codon usage (Campbell and Gowri 1990). A similar correlation between GC content and codon bias has been reported in C. sorokiniana (Cock et al. 1991). The one green alga that did not exhibit an elevated GC content was Stichococcus sp. This representative of the Charophyceae had a GC content of only $45 \%$, which is more typical of the diatoms or higher plants (Shapiro 1976). This is consistent with the notion that Stichococcus is part of the lineage that gave rise to higher land plants (Lee 1980, Pickett-Heaps 1974), and such data help to emphasize the distinction between the Charophyceae and the other members of the division Chlorophyta. Within the Chlorophyceae, M. minutum had the highest GC content, with a value of $71 \%$. We 
have been unable to find a comparably high value for any other eukaryotic organism. However, GC contents of up to $79 \%$ have been reported in prokaryotes such as members of the genus Streptomyces (reviewed in Normore 1976). The significance of a high GC content is unknown. One might postulate that high GC is related to thermotolerance because of its effect in DNA helix stabilization. M. minutum is a very robust organism, although its thermotolerance is not particularly noteworthy (Barclay et al. 1986).

These data are clearly informative in terms of the basic biology of the algae studied. In addition, the modified bases and unusual GC contents observed have important practical consequences for genetic engineering of these microalgae. DNA methylation can have detrimental effects on gene cloning; in particular, restriction enzymes must be chosen based on their sensitivity to methylation, and special E. coli hosts (mcr; Graham et al. 1990, Blumenthal 1989) should be used when cloning $\mathrm{m}^{5} \mathrm{dC}$ containing DNA (Cock et al. 1990). Methylation may also be an indicator of endogenous restriction/modification systems in the algae, which could make the development of transformation systems difficult. The GC content may also affect the selection of strategies for cloning and transformation. In the absence of specific codon bias information, high GC levels should be considered as evidence for a bias toward $\mathrm{G}$ and $\mathrm{C}$ in the codon usage when designing oligonucleotide probes based on protein sequence information. An unusual codon bias may also prevent the efficient expression of introduced heterologous genes. Thus, these data provide a useful foundation for the development of genetic engineering systems in these microalgae. 


\section{MICROALGAL TRANSFORMATION}

\section{INTRODUCTION}

Genetic transformation is the process of introducing DNA into a cell and having a gene contained on that DNA be "expressed" (read by the cell's machinery) to make a protein. In order to verify transformation, a method must be devised to detect the protein biochemically or to apply a genetic selection such that only cells producing that protein are able to reproduce. Thus, transformation requires not only the physical introduction of DNA into the cell, but also requires a means of monitoring gene entry and expression. In addition, the creation of stably transformed cell lines requires that the DNA become fixed into the cell's genome.

Progress in microalgal transformation has focused primarily on methods to assess the successful introduction of foreign DNA. A system described previously for monitoring transient gene expression, using the firefly luciferase gene, has been refined further. Much time has been expended in the development of appropriate selectable markers for microalgae that will provide a powerful selection for rare, stable transformation events.

\section{TRANSIENT EXPRESSION ASSAYS}

The first two steps in the transformation of microalgae are to develop ways of introducing recombinant molecules into the cell and assay short-term expression of an introduced gene. Work was reported previously describing a method for the introduction of the firefly luciferase gene into the green alga C. ellipsoidea (Jarvis and Brown 1991). As with higher plants, the cell covering or cell wall of microalgae presents a significant barrier to the introduction of exogenous DNA into the cells; for the studies on C. ellipsoidea, the cell wall was removed by treatment with the enzyme preparation Cellulysin. The resulting protoplasts were then induced to take up foreign DNA in the presence of polyethylene glycol (PEG) and/or calcium. Expression of the introduced gene was measured by an enzymatic assay for the protein luciferase, which catalyzes 
the oxidation of luciferin with the concurrent release of a photon of light. Luciferase was thus detected in crude extracts from cells expressing this gene by monitoring light production in a scintillation counter or luminometer. The firefly luciferase transient assay has been used to monitor DNA uptake and expression in a variety of cell types (DeWet et al. 1987, Wood and DeLuca 1987), including plants (Ow et al. 1986), but this is the first example of luciferase expression in algae.

A relatively small-scale effort has continued in the use of luciferase as a transient marker for the algae. Attempts to apply the system to other species of algae have not yet succeeded, perhaps due either to failure to introduce exogenously added DNA into the cells or insufficient expression of the marker gene. One of the attributes of the luciferase system is its sensitivity, and we have demonstrated previously that fewer than 100,000 molecules of protein in the cell extract could be detected. However, when working with recalcitrant systems such as microalgae, further improving this sensitivity would be desirable. By employing a luciferyl-CoA detection system (Promega, Inc.), we were able to achieve a four-fold enhancement of the signal relative to background for detection of luciferase in C. ellipsoidea protoplasts treated with the luciferase plasmid. This increase may help to make small signals easier to detect reliably.

\section{HOMOLOGOUS SELECTABLE MARKERS}

We are currently working to develop two genes as potential selectable markers for algal transformation. The DNA analysis data, and the precedent set in $C$. reinhardtii, suggest that heterologous selectable markers (e.g., antibiotic resistance) may not be effective in the algae. By using homologous genes, problems in promoter specificity and codon bias will not inhibit gene expression, allowing successful selection for transformed cells.

\section{Orotidine-5'-phosphate decarboxylase}

The OPD gene codes for an essential enzyme in the pyrimidine biosynthesis pathway. OPD mutants grow only if provided with an alternate source of pyrimidines, such as uracil. 
There is a positive selection for OPD mutants; OPD converts the drug 5-fluoroorotic acid (FOA) into a toxic compound, killing wild-type cells, whereas OPD mutants can grow on FOA-containing media. In addition, a relatively simple spectrophotometric assay can be used to measure OPD activity in cell extracts (Donovan and Kushner 1983). The gene has been cloned and sequenced from a number of organisms (Rose et al. 1984, Newbury et al. 1986, Ohmstede et al. 1986, Turnbough et al. 1987), and has been used successfully in several transformation systems (e.g., Buxton and Radford 1983, Boy-Marcotte et al. 1984, van Hartingsveldt et al. 1987).

Preliminary screening has shown that several microalgal strains in the NREL collection are sensitive to FOA at concentrations between 0.5 to $1.0 \mathrm{mg} / \mathrm{mL}$. The mutant selection method mentioned above has been applied to several species in the collection, and we were successful in obtaining resistant colonies from UV-mutagenized cells of the green alga M. minutum. These cells require uracil for growth and thus are putative OPD mutants. One of these mutants has been characterized more extensively. This isolate, "3180a-1," grew well on medium supplemented with $80 \mu \mathrm{g} / \mathrm{mL}$ uracil, grew very slowly at low levels of uracil $(2 \mu \mathrm{g} / \mathrm{mL})$, but showed no growth in the absence of uracil. The spectrophotometric assay was used on enriched extracts from these cells to determine whether OPD activity is in fact absent in this mutant. Preliminary results suggest that $3180 \mathrm{a}-1$ is an OPD mutant, but the activity measured in wild-type cells was very weak. It may be necessary to use a different assay to obtain confirmation of these results.

The next step in the development of this system is to isolate the wild-type algal OPD gene. Two different cloning strategies are being attempted. One approach is to clone the gene simply by complementation of the $E$. coli (or yeast) marker. Past efforts using this strategy for M. minutum failed, possibly due either to insufficient expression of the gene in $E$. coli or to the absence of the gene in the library. This approach has since been applied to $C$. cryptica, where GC content data suggest a more compatible codon bias. However, screening of a $C$. cryptica library failed to identify complementing clones. As an alternative, the regions of homology between the known OPD genes can be used as a basis for designing DNA primers for gene cloning using the polymerase chain reaction ([PCR] Saiki et al. 1988, Lee and Caskey 1990). 
We have devised a set of primers, taking into account the high GC content of $M$. minutum determined in the DNA analysis, which should allow amplification of genomic sequences containing homologs to these regions. Preliminary results are encouraging. Successful cloning of the OPD gene, in combination with the putative OPD mutants described above, should prove to be a suitable selectable marker system for use in the transformation of M. minutum.

\section{Nitrate reductase}

The NR gene has also been used successfully as a transformation marker in a number of organisms, including fungi (Daboussi et al. 1989) and C. reinhardtii (Kindle et al. 1989). Algal cell mutants lacking functional NR can be selected based on their resistance to chlorate. Cells having a functional NR protein will take up chlorate along with nitrate and reduce it to chlorite, which is toxic to the cells. The NR-minus mutants do not reduce the chlorate and so do not experience the cytotoxic effects of chlorite. Consequently, cells can be subjected to a positive selection regime by growing target organisms in the presence of chlorate and picking out resistant colonies. Using this protocol, we have isolated several putative NR-deficient mutants of $M$. minutum and of the diatom $C$. cryptica. These candidates grow in the presence of chlorate and are unable to utilize nitrate on plates or in liquid culture. Experiments completed this year have been aimed at the characterization of these mutants. Of the five mutants characterized (using biochemical assays and nutritional requirement studies), two of the mutations appear to be in the NR structural gene, two are in the molybdo-pterin cofactor, and one is of uncertain function. The structural mutants will be best suited to transformation studies; however, all of the mutants could prove interesting for studies of photosynthate partitioning in the algae.

We are currently working to isolate wild-type NR genes from both M. minutum and C. cryptica using techniques similar to those described above for isolation of the OPD gene. Initial experiments using PCR failed to amplify these sequences from $M$. minutum genomic DNA; however, amplification products were obtained when using RNA as a starting material. Once the gene is cloned, complementation of a NR-minus mutant with a functional NR gene will result 
in cells that can use nitrate as the sole nitrogen source, providing a powerful selection for transformants. 


\section{LIPID GENE CLONING}

\section{INTRODUCTION}

A gene is a specific molecule of DNA that gives an organism the ability to perform a specific function. For many genes, the DNA is "transcribed" into messenger RNA, which is then "translated" into a protein. In many cases, the protein product is an enzyme that catalyzes a particular chemical reaction. In order to genetically engineer an organism, such as a microalga, to better carry out a particular function (e.g., lipid accumulation), it is necessary to alter the DNA composition of the organism by manipulating the genes that encode proteins of regulatory significance.

There are two primary methods available for identifying a specific gene from a particular organism. In the first case, a "genomic library" is made that contains the entire genome of an organism broken down into smaller pieces; these pieces are then incorporated into the genome of bacteria or viruses so that the incorporated foreign genes are naturally amplified (i.e., the genes are "cloned"). This library of cloned DNA pieces is then screened with a labeled probe consisting of a small piece of DNA that specifically hybridizes to the cloned gene of interest, thereby allowing the investigator to quickly identify and isolate the desired gene.

Another common method for identifying a particular gene is to make a gene library consisting of DNA that was "reverse transcribed" from messenger RNA molecules present in the organism. In this case, the probe used to identify the gene of interest can be an antibody that specifically recognizes the protein product of the cloned gene.

We have succeeded in producing both antibody probes and DNA probes that can be used to identify the gene that encodes ACC from the diatom $C$. cryptica, an enzyme that has been shown in our previous studies to play an important role in the control of lipid biosynthetic rates. The procedures used to produce these probes are described below. 


\section{PROBE DEVELOPMENT}

\section{Antibody probe production}

Highly purified ACC $(100 \mu \mathrm{g})$ from C. cryptica was mixed with Freund's adjuvant and injected into two male New Zealand white rabbits. Booster injections containing $50 \mu \mathrm{g}$ of ACC were made at two week intervals. Serum from each rabbit was collected ten days after each booster injection and tested for the ability to detect ACC on Western blots (immunoblots). When the titer of anti-ACC was uniformly high (approximately 15 weeks after the primary immunization), a large amount of serum was collected from each animal and frozen. Portions of the serum were affinity-purified by passing the serum through a gel filtration column containing covalently bound ACC. The anti-ACC antibodies were eluted by low $\mathrm{pH}$ buffer (0.2 M glycine, $\mathrm{pH} 2.7$ ), followed by high $\mathrm{pH}$ buffer ( $0.1 \mathrm{M}$ methylamine, $\mathrm{pH} 11.5$ ). The buffer in these preparations was changed to sodium phosphate $(\mathrm{pH} 7)$ for storage. The affinity-purified antibodies were shown by immunoblot analysis to be highly specific for ACC. These antibody preparations should therefore work very well in gene isolation strategies requiring probes that specifically recognize ACC molecules produced in protein expression libraries.

\section{DNA probe production}

Because the gene for ACC has never been isolated from an alga or higher plant, heterologous DNA probes are not available for identification of the ACC gene from C. cryptica gene libraries. Therefore, it was necessary to determine the amino acid sequences from several different regions of the ACC protein so that possible DNA coding sequences could be derived for these regions. Highly purified ACC was subjected to cyanogen bromide-mediated proteolysis and the peptide fragments were resolved from each other by either microbore reverse phase high performance liquid chromatography or SDS-polyacrylamide gel electrophoresis. A major part of this peptide sequencing effort was carried out in collaboration with Calgene, Inc., a biotechnology company located in Davis, Calif., which specializes in agricultural crop improvement. Partial amino acid sequences for ten individual peptides were determined. 
Comparison of these sequences with the known amino acid sequence of mammalian ACC indicated that some of these peptides had a high degree of similarity with the mammalian protein. These peptides were used to design oligonucleotide primers for use in a gene amplification protocol utilizing PCR. Using this procedure, a 146 base pair (bp) DNA fragment was generated. This fragment was sequenced and shown to be highly homologous (58\% identity) with the mammalian ACC gene, indicating that a portion of the $C$. cryptica ACC gene had in fact been isolated. This $146 \mathrm{bp} \mathrm{ACC}$ gene fragment was subcloned into a plasmid vector to be used as a probe to identify the entire gene in a genomic library.

\section{ACC GENE CLONING}

We have also constructed a $C$. cryptica genomic library in a lambda phage derivative. RNA probes generated by in vitro transcription of the $146 \mathrm{bp}$ insert were used to screen this library in order to isolate the full-length gene. We have isolated four recombinant phage that contain DNA that hybridizes strongly to the 146 bp ACC probe. When included in PCRs using the same primers described above, the DNA from each of these clones serves as a template for production of a $146 \mathrm{bp}$ piece of DNA, indicating that these clones in fact contain the ACC gene. In addition, restriction enzyme digests of these clones produce DNA fragments that are the same size as DNA fragments corresponding to the ACC gene as deduced by genomic Southern blots.

\section{CHARACTERIZATION OF THE ACC GENE}

A restriction map of the gene for ACC from the diatom C. cryptica has been completed, and significant progress has been made toward determination of the complete gene sequence. Thus far, over five kilobases $(\mathrm{kb})$ of the sequence have been determined. A great deal of similarity exists between the ACC gene from Cyclotella and from mammals, particularly in the regions that encode the amino terminus and the carboxy terminus portions of the enzyme. These regions code for the biotin carboxylase and transcarboxylase activities, respectively. However, the middle 
region of the gene, encoding the biotin carboxyl carrier protein domain, is very distinct from the mammalian gene. This work represents the first ACC sequence information from a photosynthetic organism. 


\section{ENVIRONMENT, SAFETY AND HEALTH and QUALITY ASSURANCE}

During FY 1991 a major effort was directed at reaching a new standard of excellence in environment, safety, and health (ES\&H). This effort was in response to the new culture of ES\&H awareness brought into focus by the DOE "Tiger Team." In addition to a general cleanup and reorganization of the laboratories, specific hazards were dealt with as described below. Aquatic Species Project personnel also responded to the need for improved quality assurance (QA) compliance and documentation.

\section{ENVIRONMENT, SAFETY, AND HEALTH}

\section{Chemical Inventory}

An inventory of chemicals in the laboratories was updated in July of 1991 and has been updated continuously since that time. Many chemicals that were no longer needed or had passed their expiration date were given to the ES\&H section for disposal and the general housekeeping of chemicals was improved. In addition, all carcinogens were identified, separated from the main chemical inventory, and placed in secondary containment. A system was devised to mark chemicals that had been entered into the inventory, and a procedure was established to add and delete chemicals from the inventory as ordered or depleted. The inventory, which can now be accessed through the laboratory computer, includes information such as when a particular chemical was ordered, when it was received, and any hazards associated with it. The inventory has also been sorted by location for ease in determining what is in each laboratory during an emergency situation. 


\section{Material Safety Data Sheets}

Material Safety Data Sheets (MSDS) were collected for all of the chemicals found in the inventory. MSDS were also obtained for miscellaneous office, laboratory and cleaning supplies. A "Right-to-Know" center was established to make copies of all the MSDS readily available to laboratory personnel. These designated shelves also have other valuable safety information, including waste disposal logs. A system was also set up to allow MSDS for novel chemicals to be accessed from a data base using a computer in the laboratory.

\section{Chemical Labeling}

A system of labeling was adopted for all of the chemicals and solutions in the laboratories. The standardized labels provide specific information on the health, fire, reactivity, and special hazards associated with each chemical. Guidelines for labeling of aqueous solutions were established in accordance with the NREL Chemical Hygiene Plan.

\section{Electrical Safety}

To ensure electrical safety in the laboratory, a thorough inspection and a large number of modifications were carried out. The demonstration/test ponds at NREL were completely rewired.

\section{QUALITY ASSURANCE}

A QA notebook was established in which all pieces of equipment in the Aquatic Species laboratories were listed. Entries included calibration classification, applicable calibration methods, and measurement data. 


\section{REFERENCES}

Antequera, F. and Bird, A. P. 1988. Unmethylated CpG islands associated with genes in higher plant DNA. EMBO J. 7:2295-2299.

Barclay, W., Johansen, J., Chelf, P., Nagle, N., Roessler, P., and Lemke, P. 1986. Microalgal Culture Collection 1986-1987. Solar Energy Research Institute, Golden, CO, 149 pp.

Blumenthal, R. M. 1989. Cloning and restriction of methylated DNA in Escherichia coli. Focus 11:41-46.

Boy-Marcotte, E., Vilaine, F., Camonis, J., and Jacquet, M. 1984. A DNA sequence from Dictyostelium discoideum complements ura3 and ura5 mutations of Saccharomyces cerevisiae. Mol. Gen. Genet. 193:406-413.

Buxton, F. P. and Radford, A. 1983. Cloning of the structural gene for orotidine 5'phosphate carboxylase of Neurospora crassa by expression in Escherichia coli. Mol. Gen. Genet. 190:403-405.

Campbell, W. H. and Gowri, G. 1990. Codon usage in higher plants, green algae, and cyanobacteria. Plant Physiol. 92:1-11.

Cock, J. M., Kim, K. D., Miller, P. W., Hutson, R. G., and Schmidt, R. R. 1991. A nuclear gene with many introns encoding ammonium-inducible chloroplastic NADP-specific glutamate dehydrogenase(s) in Chlorella sorokiniana. Plant Mol. Biol. 17:1023-1044.

Cock, J. M., Roof, L. L., Bascomb, N. F., Gehrke, C. W., Kuo, K. C., and Schmidt, R. R. 1990. Restriction enzyme analysis and cloning of high molecular weight genomic DNA isolated from Chlorella sorokiniana (Chlorophyta). J. Phycol. 26:361-367. 
Daboussi, M. J., Djeballi, A., Gerlinger, C., Blaiseau, P. L., Bouvier, I., Cassan, M., Lebrun, M. H., Parisot, D., and Brygoo, Y. 1989. Transformation of seven species of filamentous fungi using the nitrate reductase gene of Aspergillus nidulans. Curr. Genet. 15:453-456.

De Wet, J. R., Wood, K. V., DeLuca, M., Helinski, D. R., and Subramani, S. 1987. Firefly in luciferase gene: structure and expression in mammalian cells. Mol. Cell. Biol. 7:725-737.

Debuchy, R., Purton, S., and Rochaix, J.-D. 1989. The argininosuccinate lyase gene of Chlamydomonas reinhardtii: an important tool for nuclear transformation and for correlating the genetic and molecular maps of the ARG7 locus. EMBO J. 8:2803-2809.

Donovan, W. P., and Kushner, S. R. 1983. Purification and characterization of orotidine-5'phosphate decarboxylase from Escherichia coli. J. Bacteriol. 156:620-624.

Dunahay, T. G., Jarvis, E. E., Zeiler, K. G., Nagle, N., Brown, L. M., Roessler, P. G., Ohlrogge, J. B., Cannons, A. C., and Solomonson, L. P. Genetic engineering of microalgae for fuel production. Aquatic Species Project Annual Report, October 1990, Lewis M. Brown, ed.

Gehrke, C. W. and Kuo, K. C. 1990. Ribonucleoside analysis by high performance reversed-phase liquid chromatography. Chromatography and Modification of Nucleosides, Gehrke, C. W. and Kuo, K. C., eds., Part A, Elsevier Science Publishers, Amsterdam, pp. A3-A70.

Goldschmidt-Clermont, M. and Rahire, M. 1986. Sequence, evolution and differential expression of the two genes encoding variant small subunits of ribulose biphosphate carboxylase/oxygenase in Chlamydomonas reinhardtii. J. Mol. ․ㅡ. 191:421-432.

Graham, M. W., Doherty, J. P., and Woodcock, D. M. 1990. Efficient construction of plant genomic libraries requires the use of $\underline{\mathrm{mcr}-}$ host strains and packaging mixes. Plant $\underline{\text { Mol. Biol. }}$. Rep. 8:18-27. 
Gruenbaum, Y., Naveh-Many, T., Cedar, H., and Razin, A. 1981. Sequence specificity of methylation in higher plant DNA. Nature 292:860-862.

Hershkovitz, M., Gruenbaum, Y., Renbaum, P., Razin, A., and Loyter, A. 1990. Effect of CpG methylation on gene expression in transfected plant protoplasts. Gene 94:189-193.

Hoffman, C. S. and Winston, F. 1987. A ten-minute DNA preparation from yeast efficiently releases autonomous plasmids for transformation of Escherichia coli. Gene 57:267-272.

Jarvis, E. E. and Brown, L. M. 1991. Transient expression of firefly luciferase in protoplasts of the green alga Chlorella ellipsoidea. Curr. Genet. 19:317-321.

Kindle, K. L., Schnell, R. A., Fernandez, E., and Lefebvre, P. A. 1989. Stable nuclear transformation of Chlamydomonas using the Chlamydomonas gene for nitrate reductase. $\underline{\text { J. }}$ Cell. Bio. 109:2589-2601.

Lee, C. C. and Caskey, C. T. 1990. cDNA cloning using degenerate primers. In Innis, M. A., Gelfand, D. H., Sninsky J. J., and White, T. J., eds., PCR Protocols: $\underline{A}$ Guide to Methods and Applications, Academic Press, Inc., San Diego, CA, pp. 46-53.

Lee, R. E. 1980. Phycology. Cambridge University Press, NY, 478 pp.

Mann, M. B. and Smith, H. O. 1977. Specificity in HpaII and HaeIII DNA methylases. Nucleic Acids Res. 4:4211-4221.

Mayfield, S. P., and Kindle, K. L. 1990. Stable nuclear transformation of Chlamydomonas

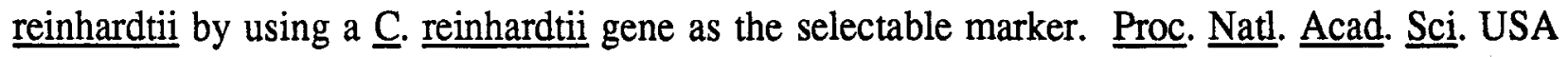
87:2087-2091. 
Messer, W. and Noyer-Weidner, M. 1988. Timing and targeting: the biological functions of dam methylation in E. coli. Cell 54:735-737.

Modrich, P. 1982. Studies on sequence recognition by type II restriction and modification enzymes. CRC Crit. Rev. Biochem. 13:287-323.

Newbury, S. F., Glazebrook, J. A., and Radford, A. 1986. Sequence analysis of the pyr-4 (orotidine 5'-P decarboxylase) gene of Neurospora crassa. Gene (Amst.) 43:51-58.

Normore, W. M. 1976. Guanine-plus-cytosine (GC) composition of the DNA of bacteria, fungi, algae and protozoa. Handbook of Biochemistry and Molecular Biology, 3rd edition, G. D. Fasman, ed., Nucleic Acids, Volume II, CRC Press, Boca Raton, FL, pp. 65-235.

Ohmstede, C., Langdon, S. D., Chae, C., and Jones, M. E. 1986. Expression and sequence analysis of a cDNA encoding the orotidine-5'-monophosphate decarboxylase domain from Ehrlich Ascites uridylate synthase. J. Biol. Chem. 261:4276-4282.

Ow, D. W., Wood, K. V., DeLuca, M., De Wet, J. R., Helinski, D. R., and Howell, S. H. 1986. Transient and stable expression of the firefly luciferase gene in plant cells and transgenic plants. Science 234:856-859.

Pickett-Heaps, J. D. 1974. Cell division in Stichococcus. Br. Phycol. J. 9:63-73.

Rose, M., Grisafi, P., and Botstein, D. 1984. Structure and function of the yeast URA3 gene: expression in Escherichia coli. Gene (Amst.) 29:113-124.

Saiki, R. K., Gelfand, D. H., Stoffel, S., Scharf, S. J., Higuchi, R., Horn, G. T., Mullis, K. B., and Erich, H. A. 1988. Primer directed enzymatic amplification of DNA with a thermostable DNA polymerase. Science 239:487-491. 
Selker, E. U. 1990. DNA methylation and chromatin structure: a view from below. TIBS 15:103-107.

Shapiro, H. S. 1976. Distribution of purines and pyrimidines in deoxyribonucleic acids. Handbook of Biochemistry and Molecular Biology, 3rd edition, G. D. Fasman, ed. Nucleic Acids, Volume II, CRC Press, Boca Raton, FL, pp. 241-311.

Silflow, C. D. and Youngblom, J. 1986. Chlamydomonas reinhardtii tubulin gene structure. Ann. NY Acad. Sci. 466:18-30.

Turnbough, C. L., Kerr, K. H., Funderburg, W. R., Donahue, J. P., and Powell, F. E. 1987. Nucleotide sequence and characterization of the pyrf operon of Escherichia coli K12. J. Biol. Chem. 262:10239-10245.

Van Etten, J. L., Schuster, A. M., Girton, L., Burbank, D. E., Swinton, D., and Hattman, S. 1985. DNA methylation of viruses infecting a eukaryotic Chlorella-like green alga. Nucleic

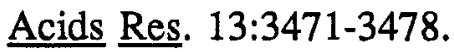

van Hartingsveldt, W., Mattern, I. E., van Zeijl, C. M. J., Pouwels, P. H., and van den Hondel, C. A. M. 1987. Development of a homologous transformation system for Aspergillus niger based on the pyrG gene. Mol. Gen. Genet. 206:71-75.

Waalwijk, C. and Flavell, R. A. 1978. MspI, an isoschizomer of Hpall which cleaves both

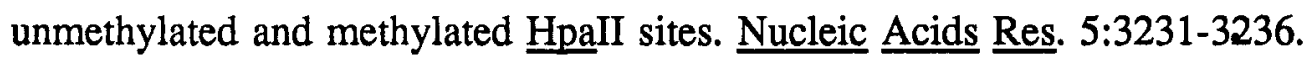

Wood, K. V. and DeLuca, M. 1987. Photographic detection of luminescence in Escherichia coli containing the gene for firefly luciferase. Anal. Biochem. 161:501-507. 


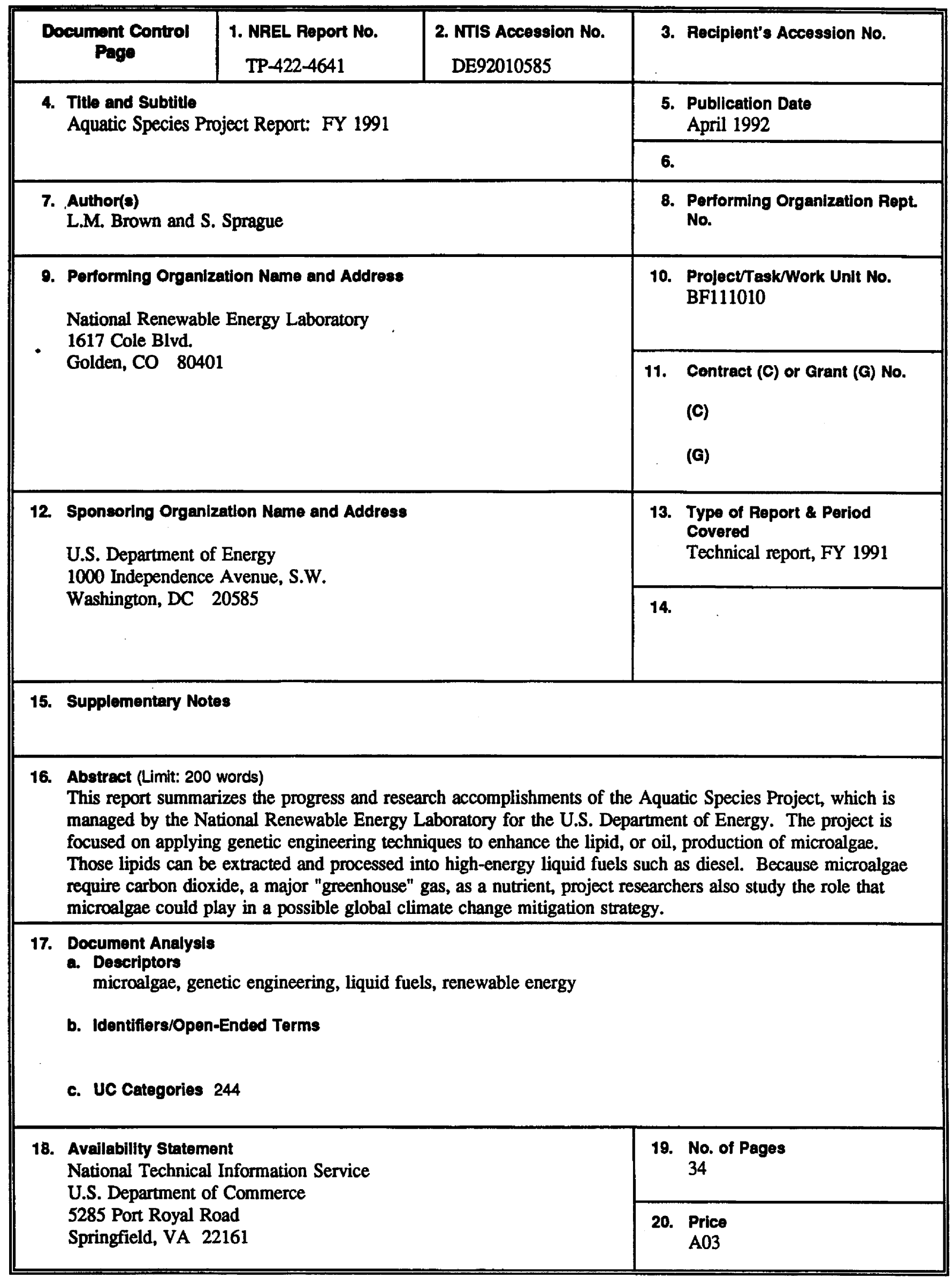

Form No. 0088E (6-30-87) 